\title{
Negative Aspects of Nonrealization of Motherhood - Opinions and Sentiments of Childless Women
}

\begin{abstract}
The issues presented in this publication are situated within the framework of qualitative research. The research concerns negative aspects stemming from not experiencing motherhood present in the narrative of women aged 35-42 years old. The aim of the research is identifying the disadvantages of childlessness as perceived by mature women. The research was performed on 38 women. The criterion of the research sample selection, apart from age, was being unmarried (a woman's marital status was "unmarried", "divorced" or "widow"; women in cohabitational relationships were not excluded) and childless.

The surveyed women were therefore asked the question: Do you notice some losses resulting from not functioning in the role of a mother? On the basis of central topics, i.e. topics that prevailed in the interviews, 5 response categories were determined: discrimination in the workplace, social stigma, discrimination in public space, not following the road leading to happiness and fulfilment, and loneliness in old age.

Key words: motherhood, mother, childless woman, intended childlessness, voluntary childlessness, social stigma.
\end{abstract}

\section{Introduction}

Until recently, it was important to fulfill the motherhood requirements within marriage, a situation symbolized by the triple stereotype of love-marriagemotherhood. People joined in marriage were expected to have offspring.

Our times are characterized by many new phenomena, such as: single motherhood and fatherhood, couples' childlessness by choice or homosexual couples bringing up children. The development and extent of such phenomena 


\section{Dorota Ruszkiewicz}

forces a change in their perception, putting an end to their marginalization, as well as imposing the range and pace of adapting the social and demographic policy of the state.

Currently a woman has a wider choice of roles to play. Her obligations and goals are not limited to one role, that of a mother. As professional work becomes more and more important for women, and as the domestic duties are more and more often shared evenly by both partners, the perception of family and social roles appropriate for women changes. Motherhood is no longer associated with a social obligation, but with a woman's personal choice. There is an increase in the number of women who postpone the decision about motherhood or renounce childbearing completely. Joanna Pawelska is of the opinion that "the increase in childlessness by choice undoubtedly transforms societies" [2005, p. 33]. By refusing the biological, procreative function of the relationship, men and women decide also to rupture the chain of values and traditions, of the cultural heritage in a broad sense. Therefore, the lack of progeny influences not only the rate of natural increase, but also the transfer of a given community's elementary cultural values [Adamski 2002, pp. 36-38]. On the other hand, the choice to remain childless is for many women a possibility to realize their own educational and professional projects, whose presence in women's biographies grows stronger and more frequent. The possibility to dedicate more time to the partner and to herself may also lead to greater intimacy and love [Slany 2002, p. 112].

Nevertheless, there are cases in which childlessness is a compulsion, not a woman' conscious decision. Stress, inappropriate eating habits, unreasonable dieting, insufficient amount of sleep, excessive workload, lack of leaves and postponing the decision about childbearing are factors leading to women's childlessness.

\section{Research Methodology}

The issues presented in this publication are situated within the framework of qualitative research. The research concerns negative aspects that stem from not experiencing motherhood present in the narrative of women aged 35-42 years old. The aim of the research is identifying the disadvantages of childlessness as perceived by mature women. The main research question is: What are the losses caused by not experiencing motherhood, indicated by the surveyed women?

The research was based on one of case study methods, i.e. the biographical method. The data were acquired by a modified technique of the autobiographical narrative interview. 


\section{Research sample selection}

The research was performed on $38^{2}$ women aged 35-42. The criterion of the research sample selection, apart from age, was being unmarried (a woman's marital status was "unmarried", "divorced" or "widow"; women in cohabitational relationships were not excluded) and childless.

\section{Sociodemographic profile of the surveyed women - selected characteristics}

Table 1. Marital status of the surveyed women [N=38]

\begin{tabular}{|l|l|l|}
\hline responses & N & $\%$ \\
\hline unmarried & 16 & 42.1 \\
\hline divorced & 18 & 47.4 \\
\hline widow & 4 & 10.5 \\
\hline
\end{tabular}

Source: own study.

The majority of the surveyed women $(47.4 \%$, or 18 individuals) are divorced. The number of unmarried women is only slightly lower $(42.1 \%$, or 16 individuals). Only 4 women $(10.5 \%)$ are widows.

Table 2 . The surveyed women having a partner $[\mathrm{N}=38]$

\begin{tabular}{|l|l|l|}
\hline responses & N & $\%$ \\
\hline I haven't got a partner, I'm single & 16 & 42.1 \\
\hline I have a partner and we live together & 12 & 31.6 \\
\hline $\begin{array}{l}\text { I have a partner, but we don't live together; we just date; sometimes we } \\
\text { live together for a short time }\end{array}$ & 10 & 26.3 \\
\hline
\end{tabular}

Source: own study.

The majority of women $(42.1 \%$, or 16 individuals) declared that during the research they were single, that is, they did not have a partner. One-third of the surveyed women is in an informal relationship and live with their partner $(31.6 \%)$. A similar percentage $(26.3 \%)$ of women have a partner, but each of them has their own flat; they live together only from time to time.

2 In qualitative research, the requirement of sample representativeness is disregarded, similarly to the requirement of reliability (allowing to repeat the research with the same instrument). Individuals are selected for epistemic reasons. Therefore, there is no emphasis on a large number of research subjects. 
Table 3. Type of childlessness of the surveyed women [N=38]

\begin{tabular}{|l|l|l|}
\hline responses & N & $\%$ \\
\hline unintended childlessness & 31 & 81.6 \\
\hline voluntary childlessness & 7 & 18.4 \\
\hline
\end{tabular}

Source: own study.

A vast majority of women (81.6\%, or 31 individuals) expressed the opinion that they do not function in the social role of a mother because their life went that way. Only 7 women (18.4\%) declared it was their voluntary decision.

\section{Research results}

Many women cite both negative and positive aspects of motherhood. The role of a mother inspires ambivalent feelings. What one mother perceives as a positive consequence of experiencing this role may seem negative to another. However, as proved by the research results, there are some universal premises that may be identified as bad or good values caused by having children. The surveyed women were therefore asked the question: Do you notice some losses resulting from not functioning in the role of a mother? On the basis of the central topics, i.e. the topics that prevailed in the interviews, 5 response categories were determined.

Table 4. Negative aspects resulting from not experiencing motherhood [N=38]

\begin{tabular}{|l|l|l|}
\hline responses & N & $\%$ \\
\hline discrimination in the workplace & 14 & 36.8 \\
\hline social stigma & 32 & 84.2 \\
\hline discrimination in public space & 11 & 28.9 \\
\hline $\begin{array}{l}\text { not following the road leading to happiness and } \\
\text { fulfilment }\end{array}$ & 31 & 81.5 \\
\hline loneliness in old age & 17 & 44.7 \\
\hline
\end{tabular}

The surveyed women indicated several disadvantages.

Source: own study.

\section{Discrimination in the workplace}

The discrimination against women in the domain of professional work may be determined, according to Patrycja Zwiech [2011], by socio-political, economical and socio-cultural factors related directly both to the discriminating and the discriminated. In their professional life, women often suffer from discrimination, mainly in the financial domain. Different data indicate that the phenomenon of discrimination against women in the professional setting remains very common. Although practical and scientific knowledge of methods of fighting it grows 
more widespread, the changes are small and unsatisfying for most communities [Karaszewicz, Bata, Lewandowski 2006, p. 261].

Discrimination in the workplace may concern such categories as: gender, age, race, nationality, marital status, disability, sexual orientation, religion and religious beliefs, political opinions, membership in political organizations and having children.

According to the stereotype, it is the working mothers that are discriminated at work. Directors and managers often treat them as a necessary evil, depriving them of the possibility of advancement and pay raise, hindering their career. However, it turns out that they are not the only ones who suffer from a lack of tolerance and understanding. The research proves that childless women receive a similar treatment.

\section{Forms of discrimination indicated by the surveyed women}

\section{Being made redundant first in case of the company's downsizing}

Last year, my work place was downsized. In reality, they didn't know who to dismiss, because all of us worked very diligently. That's when they started to bint that single people, without families, should be made redundant first. They will manage somehow because they don't have children to provide for. It's true that a childless woman doesn't have to worry about children, but she, too, must pay the bills and the rent, pay off the loan. In other words, she, too, wants to live. In the end, both mothers and childless women were made redundant. But having children is some kind of bargaining card in case of redundancy $[36 \mathrm{y} / 0]$.

\section{Less convenient leave dates and more duties because of replacements}

For some time I've been noticing that when leave dates are planned, women with children are privileged. If two women, a childless one and a mother, want to take leave at the same time, the one with no children always has to step back. The mother's argument goes: we've already booked a house for the whole family, children are set to go, we can't go at any other time because children leave for a summer camp. A single woman can always change the date of the trip, or she can renounce the trip altogether. After all, she's not tired, as she doesn't bring up a child [39 y/o]. Another response: Obviously, when someone is ill or takes leave, their duties pass to somebody else. Usually it is a childless woman because she has more time for professional work, since she doesn't have a family. What's more, she takes leave more rarely than her colleagues with children, so she often replaces them when they take care of an ill kid and cook soup for the family. When the child recovers, it's the mother that falls ill because her son or daughter has passed it to her. So the childless worker continues to replace her colleague [37 y/o].

3. Obligation to be constantly available and ready to move to another branch of the company, even if it is in another city

If there is a need for a worker to perform a task outside their normal duties, this worker will more often happen to be somebody childless than somebody with a family [42 y/o]. Another one: 


\section{Dorota Ruszkiewicz}

I used to work at the post office in Piotrkón Trybunalski. Because of changes in organization and management, some workers had to relocate to other offices in Poland, for example in Lódź or even Katowice. Those who had small cbildren stayed in Piotrków. The manager believed it was a crucial argument for not moving such a worker from Piotrków. A childless person will have no problem with living in Katowice from Monday to Friday. It doesn't cost anything at all, nor do the train tickets $[39 \mathrm{y} / 0$ ].

\section{Experiencing more remarks of erotic and sexual nature}

I'm a single woman, and I believe that because of that, some men think that they can pick me up and compliment me in an inappropriate manner, and that I will love that. My colleagues who are mothers and wives don't have such experiences. It's obvious especially during "awaydays". A married woman and a mother belongs already to some man, so no one will harass her. A single woman is a different story. You can always accost her because she isn't spoken for, she's available. Such men don't care what she wants [38 y/o].

\section{Being belittled by other women, isolation}

One of the surveyed women pointed out that women who did not form a procreative family are belittled or even treated as a menace. It happens mainly in big corporations, where such women are isolated. It looks like that: mothers and married women form one group, and single women another group. They must be linked by some common interests. But at the same time, single women, especially those without children, are a menace, because they can take away your man $[37 \mathrm{y} / \mathrm{o}]$.

The responses cited above prove that childless and single women fall victim to a specific kind of mobbing in the workplace. Because of the patriarchy that dominates in the Polish culture, a woman is still judged through the perspective of motherhood. Single and childless women cannot benefit from many privileges granted to mothers. Those rights are conferred to them only when they become "real women" through motherhood.

\section{Social stigma}

Erving Goffman [2005, p. 35], the author of the social stigma theory, defines individuals bearing stigma as those "who possess a social attribute that is deeply discrediting and who are perceived as less worthy for that very reason". Another definition of the stigma points out that "in this process, many forms of social behaviour or attributes are subjectively perceived as social disapproval, becoming discreditable in others' eyes, and allow for exclusion from normal social interactions, which in a long run leads to identity dysfunctions" [Czykwin 2000, p. 67]. Social stigma, as defined by Iwona Kudlińska [2012, p. 179], is “a complex phenomenon, the source of which lies in other phenomena, such as labelling, stereotyping and discrimination". 


\section{Social perception of the childless as experienced by the surveyed women}

\section{Cold, egoistic, selfish, self-centred}

A woman's identity is defined by a set of social expectations regarding her behaviour and the range of activities subordinate to feminine roles, as well as characteristics, both psychological and physical, that women should have. From that, we can conceive a general stereotype of feminity which depicts the woman chiefly as the one who provides emotional support to others, takes care of the children, runs the house and is responsible for its organization [Kosakowska 2006, p. 92]. There are many good traits attributed in general to women-mothers, such as: warm, cordial, affectionate, caring, loving, kind, devoted, empathic. If a woman does not have a child, she is often perceived as cold and egoistic. Most of my friends have children, so from time to time we bring up the topic of motherhood. I listen attentively to their stories about rearing children, about what they encounter and experience. I say that I can't imagine being pregnant and giving birth. It doesn't mean I don't like children. If my sister asks me to look after her children, I don't refuse and I even find pleasure in being with them. But I can't see myself in the role of a biological mother. Once a friend told me she'd buy me a bed warmer for a present because I was a cold woman. She also gave me an invaluable piece of advice, saying that I should rethink my decision because otherwise, when I grew old, I'd only have a rubber hot-water bottle to cuddle with [42 $\mathrm{y} / \mathrm{o}]$.

The response quoted above proves that childless people are still stereotyped as those who don't like children. On the contrary, in reality many childless women fulfil themselves perfectly in professional roles involving children (for example, early-years teachers in childcare centres, doctors, nurses, school teachers), as well as in family roles as aunties who provide financial and emotional support to their family systems.

It's true I don't pretend to be deligbted by every newborn baby. That's why I risk being perceived as cold. What's more, I'm accused of not having children because I'm afraid of responsibility [39 y/o]. Meanwhile, an opposite view is possible; namely, that the people who consciously abstain from procreation are very responsible. They know that they have to fight for their position on the job market and constantly improve their skills. They are aware of the responsibility induced by giving birth to a child. They don't want their children to be neglected or unhappy. The decision to become a parent takes place when a person is certain to be able to lead a stable life during the next dozen years. I grew up in a family that was constantly busy and exhausted. My mum worked in a factory in Lód: My dad was in the Betchatón mine, and after work, he earned extra money doing other jobs. I was one of three children. We all grew up wearing keys bung around our necks. Mum got up at 5 to prepare dinner. When dad came home, he was tired and never took care of us. As far as I remember, he never played with us, never went with us anywhere, even for a walk. I wouldn't want my children to have a similar childhood [41 y/o]. 


\section{0}

\section{Dorota Ruszkiewicz}

Childless women are also accused of egoism and living at the society's expense. I've been told that I don't have a child because I prefer to care for myself than for the kid, to have a bigher life standard [38 y/o]. The quoted woman refutes these claims later in her response, arguing that: It must be emphasized that people who bave children can also be guilty of egoism. Some people think: "I'll have children, so they'll support me when I'm old". It's very easy to judge others. Everyone should give some thought to what's best for the child. If somebody renounces parenthood, maybe it's not egoism that motivates them, but sensitivity and consciousness of their own nature, or more importantly, of their shortcomings? I think, that sensitive people, who reflect upon their decisions, choose the childlessness option. Especially when they see what's happening around them: economic problems, genetic diseases, pathologies. These people don't want to introduce a child to such a world. That's a proof of a great empathy towards the other person who could be born into this world, not of their egoism [36 y/o].

\section{Unhappy, poor, lonely, unfulfilled}

The society's general perception is that the lack of children is associated with sterility and unhappiness. There is no doubt that women who experience unintended childlessness are in a very difficult and painful situation. The personal tragedy is amplified by the way they are perceived by the society. It's true that I feel sad, lonely and unfulfilled because of not being a mother. However, I make an effort to function somehow in the world. Not experiencing motherhood is one of the reasons that made me take up self-therapy. I try to cope. But it hurts me when, for example, my friends stop talking about their children, allegedly out of concern for me. Such behaviour only intensifies my sorrow [40 y/o].

Nevertheless, there are women who consciously renounced procreation, but are still perceived by other people as unhappy and lonely. My family and friends tell me that children cement the relationship. Meanwbile, we are a proof that it's possible to be happy without children. Our family and friends think, however, that we only say that, and that in reality we are unbappy [39 y/o]. It is a myth that a couple without a child probably only pretends to be happy. That stereotype makes it possible to sustain the cultural norm of forming a family composed of a mum, a dad and children.

By encouraging procreation, family members want to fulfil their own needs: being a grandma, a grandpa or an auntie. I remember when my parents used to ask me: "When are we going to have grandcbildren?". Mum never talked about anything else but the child that should be born and why we hadn't decided to have it yet. She argued that the maternal instinct appears after the child is born. Even my friend repeatedly tells me that I am going to regret my decision, but it will be too late to have a child then, and I will be alone when I'm old" [38 y/o].

\section{Materialist, pursuing a professional career}

The result of the research performed by Helena Marzec [2007, p. 118] on female fourth- and fifth-year students ${ }^{3}$ show that $23 \%$ women chose a professional

3 The research was performed in 2005 (which is why the fourth and fifth year are cited) on students of pedagogy and history (218 women and 150 men) at the Piotrków Trybunalski branch of 
career as the principal value, whereas $33 \%$ chose a child. The majority (44\%) chose both a career and a child. Of course, reconciling a professional career with having a child may be treated as purely declarative and impossible to realize in the future. The research performed by Stanisław Kowalik [in: Świętochowicz 2012] concerning gender proves that there is an increase in the number of women of mixed gender. What is more, according to the social psychologist, the majority have both strong feminine and masculine aspects. They are happier than women who have exclusively feminine traits, they succeed more often, and they have a higher quality of life. At the same time, they are faced with a serious dilemma: give birth to a child or pursue a career? The social pressure being strong, choosing the second option requires much courage.

One of the surveyed women found that courage: I graduated from the University of Warsaw and the Warsaw School of Economics, I have a doctorate, I work at the university as a lecturer, I run my own business. In short, I have a lot of duties and I can't be certain that I could provide a good childhood to my child if I gave birth to it now. I speak openly about my lack of desire to have a child, but people don't like it. They tell me I'm a careerist who doesn't know what is really important in life $[37 \mathrm{y} / \mathrm{o}]$. Another respondent resorts to lying in order to avoid being called a careerist or a materialist: For the sake of peace and quiet, we tell my partner's family that he's sterile, and to my family, that I am infertile [38 y/o]. Another one evades the question: I say that I'm all for a child, just not now [36 y/o].

\section{Discrimination in public space}

Some childless women admitted they feel discriminated against in everyday life. In their opinion, some parents are convinced they have a right to privileged treatment stemming from having children.

\section{Mothers with prams blocking the passage}

I often see a situation like that. Two mothers with prams walk beside each other, talking. It won't occur to them to make way for another passer-by loaded down with shopping bags $[36 \mathrm{y} / 0$ ].

2. "Shh, children are asleep"

Everybody knows that small children sleep for a great part of the day. But does it mean that childless people cannot talk or laugh freely for example on their own balcony? "Please, be quiet, the kid's just fallen asleep", says the neigbbour [39 y/o].

\section{Flat not adapted to child's needs}

\section{My friends refused my invitation to a birthday coffee, saying that there are no safety covers on}

the Świętokrzyska Academy in Kielce (currently the Jan Kochanowski University in Kielce). The goal of the research was to find the answer to the question: What is more important in human life: a child or a professional career? 


\section{Dorota Ruszkiewicz}

the sockets in my flat, that I keep glass vases on low shelves and that furniture has sharp edges $[39 y / 0]$.

\section{No "childfree zones"}

In modern societies, parents have the possibility to spend time with children out of home, for example, in cafés or in restaurants. According to the respondents, kid-friendly restaurants are necessary, and there should be more of them. At the same time, they are of the opinion that the needs of childless people who would like to spend a nice afternoon talking over coffee should not be neglected. A quite popular and crowd-pleasing restaurant in Eódź, on Piotrkowska Street, turns into a small kindergarten during the weekend. There are prams everywhere, the floor is littered with toys, dummies, bibs. Children crawl under the tables, and their parents beam with joy. I can't really hear what my interlocutor is saying to me because of the noise made by children. And there's also changing nappies [39 y/o].

What are, then, the expectations of the childless? They subscribe for the idea of a child-friendly city that at the same time respects the comfort of customers without children. In their opinion, it would be a good idea to establish separate rooms for customer with children and those without. After all, it's possible to have a separate room where the childless could relax, and another one for parents with children. The parents would probably be quite satisfied, because it would lessen the stress and embarrassment caused by unruly children. The childless would avoid stress, too, because they wouldn't risk being attacked by crawling, screaming children. They could feast in peace, gossip over coffee, or read the morning newspaper [41 y/o].

\section{Not following the road leading to happiness and fulfilment}

All women who said their childlessness was unintended affirmed that someone who is not a parent will never be truly happy and fulfilled. Happiness is ,the state of ultimate satisfaction.... It is never given, but always results from human activity; usually it is equated with work performed by choice.... Nevertheless, happiness which is felt the strongest and appears in its purest form is often associated with the most primal form of sentiments: the consciousness of one's existence and activity" [Julia 2000, pp. 381-382]. There are many things that can make someone happy. Some people draw happiness from the work they perform. Others find it in the possession of material goods. Yet another group thinks that giving some of their own happiness to others makes the donors happy. Finally, people who are deeply religious believe that true happiness can only be achieved in the Kingdom of Heaven.

Monika Majewska is of the opinion that ,a modern woman looking for happiness looks above all for herself, for what is pleasant, comfortable, relaxing, easily available. She cares about her self-development - the development of her 
career: courses, training sessions, business trips; she cares about her appearance: visits at the beautician's, the hairdresser's, wellness centres; she cares about the leisure: journeys, trips, relaxation, sport" [2005, p. 302]. It is impossible not to agree with the words above. However, as proved by the research results, motherhood is also one of the roads to happiness. The recurring themes within the analyzed domain are:

\section{Loving and being loved selflessly}

According to John Paul II, „no one can find themselves in any other way than through a selfless gift of self, being a person as a self-defining subject. A woman becomes a woman in the full sense when she can offer selfless love in a relationship with another person" [Majewska 2005, p. 303].

Personal and financial success isn't the only road to happiness and fulfilment. You pursue your career, you earn quite a lot of money, you go on exotic holidays, you enjoy yourself. But if you think about it some more, all of that is just staving off boredom. And at some point, a reflection must come: what have I really done with my life? What's the point of all that? After all, it's not about a luxurious apartment with great furnishings, it's not about being attractive and feminine. And suddenly you get the revelation that life without love is pointless and devoid of any deeper sense. But I'm not talking about any love, just the unconditional one. The one that only children can give [39 y/o]. Another response: I love my partner, but I'm not sure if it's a selfless love. To be in a relationship with me, he had to meet certain conditions, such as education, physical attractiveness or appropriate personality traits. Motherly love must be some special kind of love. I can feel that longing for loving somebody selflessly $[41 \mathrm{y} / \mathrm{o}]$. That response provides a pertinent definition of motherly love, which, according to Erich Fromm, „by nature is not subject to any conditions. The mother loves the newborn child because it is hers, not because it fulfilled some particular condition or met some specific requirements of hers" [Mandal 2003, p. 29].

\section{The child would only be with us}

My friend used to tell me repeatedly: if you can't find a man, get yourself a child, at least. You won't be alone, and your mum will help to bring it up. Of course, I didn't listen to her advice, but I'm certain that a child can protect us from loneliness $[40 \mathrm{y} / 0]$. Another response: The man can leave us at any time, but the child will always stay with the mother. Whatever happens in our life, our child will always be with us [39 y/o].

It would be inappropriate to conclude that being a mother is an antidote to loneliness. However, the responses quoted above indicate that the surveyed women perceive the child as someone who will never leave, who will always love, who will not betray nor abandon. When life becomes extremely difficult, it is the child that is the force linking the woman to the life and the world.

\section{Loneliness in old age}

Growing old is an inevitable process, so it concerns everyone, regardless of gender, education or social role. Although the surveyed women are young, and 


\section{Dorota Ruszkiewicz}

although some of them have a partner, friends, acquaintances, as well as warm and intimate relationship with brothers, sisters and parents, they already fear loneliness in old age. The family of origin is the closest environment for them, but in the context of the described issue, the lack of procreational family seems to be of crucial importance in women's thinking about life's transience and about their own old age.

\section{Parents will pass away some day}

Some respondents fear the parents' passing away. They think less about their own old age than about their future situation. The older they parents are, the more intense their fear is. It is also amplified if one of their parents no longer lives.

What I fear most is parents passing away. I think that if a woman has a busband and a child or children, it is somehow easier for her to find her place in a reality without her parents. I'm not saying the loss is less painful. I think, however, that if you have a family, you still have someone to live for. Otherwise, you're left all alone in this world [39 y/o]. Another response: I lost my dad when I was 33. Now I only have my mum, who is 71 . What's more, I'm a single child. I know I'll be alone in the future, and I'll have to cope with my life alone. I'm certain that if I had a cbild, I wouldn't feel this terrible fear of the future which seems very lonely and sad to me $[40 \mathrm{y} / 0$ ].

\section{Lack of support and care from the children}

Family members are obliged to provide help, support and care to each other. All problems in life are solved more easily if one has people that can actually be counted on. Especially elderly people, who experience many moments of weakness every day, need the support of their family, including children.

A sick. person can't survive even one day on their own. When my dad was defeated by cancer, be didn't get out of bed. I and mum were constantly at his side. Someone who doesn't have a busband or cbildren cannot stay at home in a situation like that. Such person is condemned to a medical care institution. And that's frightening! [40 y/o].

Drawing upon observations of lonely elderly people they know, some women concluded that they do not have anyone who would help them in everyday tasks. According to them, a person who has no children cannot depend on somebody else's selfless help in such activities as shopping, lighting the stove, going to the doctor, cleaning, cooking or doing laundry. Even if somebody does offer help, it is usually a one-time effort, not a regular one. Even the kindest neighbours or cousins won't visit a lonely elderly person to help her on a regular basis. If they have time, if they feel like it, they'll probably come, ask "bow are you" and do some favour for her. But they are, after all, strangers, so they can't be expected to constantly take care of a neighbour or an auntie. I think. that only children could be expected to do so [38 y/o].

Another important matter is the lack of financial support. The surveyed women stereotypically associate old age with poverty. Retirement not only changes the 
elderly person's daily routine, but also worsens their financial situation, because the pension becomes the only means of supporting oneself. Ignoring the issue of the pension rate, the respondents said that nowadays, pensioners do not have the possibility to earn extra money on the side. That is why they are convinced that when they reach old age, they will not have anyone who will support them financially when they need it. Every month, I buy medicines for my mum. I do it with pleasure, but I think to myself it's good that mum has me. Nobody will help me like that when I am old [35 y/o].

At the same time, childless women start to plan their old age earlier than other people, knowing that they will not be able to count on adult children's help. The childless do not support financially children or grandchildren, so they can secure financially their own future. I'm still too young to save towards my old age. But I'll think about it in ten years or so. While my friends will be organizing costly wedding receptions for their children or giving money to their grandchildren, I will strive for the best financial situation possible, in order to live decently in my old age and cope somehow [37 y/o].

Childless and single women build a support network for years: they cultivate friendships, good relations with neighbours, acquaintances, male and female colleagues. Friends are a significant element of the respondent's social background. I still keep in touch with my friend from the university. I treat her like a sister. The older I get, the more involved I am in cultivating that relationship. What I say may be egoist, but I do it, among other reasons, so that this friendship lasts as long as possible, and I'm not completely alone in my old age [ $42 \mathrm{y} / \mathrm{o}]$. The social background of the surveyed women is also composed of colleagues, people they created close relations with by participating in the formal structure of the workplace. I met some of my friends at my workplace. We meet not only at work, but also outside of it. We go on holidays together, we celebrate New Year's Eve, we take part in annual celebrations like our name days or birthdays. They are a sort of substitute family for me [39 y/o]. The respondents also place acquaintances and neighbours in their network of social support, but these relationships are frail, short-lived and non-committal. I try to live in harmony with my neighbours. We are not very close. Actually, the relationship is pretty formal, for politeness' sake. But I hope they would belp me if I were in need [37 $\mathrm{y} / \mathrm{o}]$.

The responses quoted above correspond to the opinion Aldona Żurek expresses on the topic of the social relations of single people, who "devote their free time not only to realizing their passions and hobbies, but also to meeting people that are important to them. On workdays and holidays, as well as when they are on leave, single individuals constantly meet their friends and acquaintances, contact their colleagues and visit their relatives. One reason for such behaviour strategy is strengthening and expanding the range of social relations, which is supposed to combat the feeling of loneliness" [2003, p. 61].

It is therefore possible that there exists a group of childless women who are no less happy than women-mothers. That, however, is true for those women 


\section{Dorota Ruszkiewicz}

who consciously decided not to have children. Those whose childlessness was not intended and who did not fully accept their situation are susceptible to depression and loneliness in old age.

Themes co-occurring with the central theme were defined as marginal. They included: sadness caused by not celebrating the Mother's Day, regret that the parents cannot function in the social role of grandparents, not experiencing such moments as: going to the kindergarten or to the school on various celebrations, or preparing the child for the First Communion, lack of concern for a Christmas present, Christmas that is not joyful enough, lack of commotion at home caused by children activity.

The research results concerning the negative aspects resulting from not experiencing motherhood allow for following conclusions:

1. Childless women are prone to social stigma (32 responses). The negative traits generally attributed to them include: cold, egoist, selfish, self-centred, materialist, careerist. What is more, they are perceived as unhappy, poor, lonely and unfulfilled.

2. Childless women experience discrimination in the workplace (14 responses). The forms of discrimination cited by the surveyed women include: being made redundant first in case of company's downsizing, less convenient leave dates and more duties because of replacements, the obligation to be constantly available and ready to move to another branch of the company, even if it is in another city, experiencing more remarks of erotic and sexual nature, being belittled by other women and isolation.

3. Childless women experience discrimination in public space (11 responses). The surveyed women believe that some parents are convinced they are entitled to privileged treatment due to having children.

4. All women for whom childlessness was not intended affirmed that someone who is not a parent can never be really happy and fulfilled (31 responses).

5. Childlessness causes also the fear of loneliness in old age (17 responses).

\section{Bibliography}

Adamski F. (2002), Rodzina. Wymiar społeçno-kulturowy, Wydawnictwo Uniwersytetu Jagiellońskiego, Kraków.

Czykwin E. (2000), Stygmat społeczny, Wydawnictwo Naukowe PWN, Warszawa.

Goffman E. (2005), Piętno, rožważania o žranionej tożsamości, trans. A. Dzierżynska, J. Tokarska, Gdańskie Wydawnictwo Psychologiczne, Gdańsk.

Julia D. (2000), Stownik filozofii, trans. K. Jarosz, Wydawnictwo „Książnica”, Katowice.

Karaszewicz K., Bata A., Lawendowski R. (2006), Dlaczego kobietom trudniej odnieść sukces zawodowy? Utajone stereotypy i uprzedzenia wobec kobiet w pracy [in:] A. Chybicka, M. Kaźmierczak (ed.), Kobieta w kulturze - kultura w kobiecie. Studia interdyscyplinarne, Oficyna Wydawnicza „Impuls”, Kraków, pp. 245-268. 
Kosakowska N. (2006), Kobiety w stereotypowych i niestereotypowych rolach ptci-Polska $i$ Indie. Porównanie międzykulturowe [in:] A. Chybicka, M. Kaźmierczak (ed.), Kobieta w kulturzekultura w kobiecie. Studia interdyscyplinarne, Oficyna Wydawnicza „Impuls”, Kraków 2006, pp. 91-110.

Kudlińska I. (2012), Stygmatyzacja społeczna jako strategia dyskursywna biedy i jej rola w procesie wykluczenia społecznego, „Kultura i Społeczeństwo”, no 1, pp. 175-189.

Majewska M. (2005), W poszukiwaniu szczesscia. Psychologia egzystencjalna $i$ logoterapia w odpowiedzi na dylematy wspótczesnej kobiety [in:] K. Gąsior, T. Sakowicz (ed.), Pedagogika spoteczna w stu̧̇bie rodzinie, tom 2, „KALIGRAF”, Kielce, pp. 301-307.

Mandal E. (2003), Kobiecość i meskość, Wydawnictwo Akademickie „Żak”, Warszawa.

Marzec H. (2007), Dziecko czy kariera zawodowa problemem wspótczesnej rodz̧iny [in:] H. Marzec. M. Pindera (red.), Problemy rodziny na poczqatku trzeciego tysiaclecia, t. I, Naukowe Wydawnictwo Piotrkowskie, Piotrków Trybunalski, pp. 113-121.

Pawelska J. (2005), Cechy współcæesnego macierzyństwa, „Małżeństwo i Rodzina”, no 1-2, pp. 28-39.

Slany K. (2002), Alternatywne formy życia mał̇̌nénso-rodżinnego w ponowoczesnym świecie, Zakład Wydawniczy „NOMOS”, Kraków.

Święchowicz M. (2012), Bezdzietni żyja pod presja, „Newsweek”, 3.09., (http://polska. newsweek.pl/bezdzietni-zyja-pod-presja,95622,1,1.html (access 4.12.2014).

Zwiech P. (2011), Rodzaje dyskryminacji kobiet na rynku pracy, „Polityka Społeczna, no 4 (http://www.ipss.com.pl). 4.12.2014.

Żurek A. (2013), Single. Między samotnościq a wspólnotowościq [in:] K.L. Kuklińska (ed.), Singlizm. Nowy styl życia w ponowoczesnym świecie, Wydawnictwo Trio, Warszawa, pp. 4969. 